\title{
One-pot synthesis of diaryliodonium salts from arenes and aryl iodides with Oxone-sulfuric acid
}

\author{
Natalia Soldatova ${ }^{1}$, Pavel Postnikov ${ }^{1}$, Olga Kukurina ${ }^{1}$, Viktor V. Zhdankin ${ }^{1,2}$, \\ Akira Yoshimura ${ }^{1}$, Thomas Wirth ${ }^{*}$ and Mekhman S. Yusubov ${ }^{* 1}$
}

\section{Full Research Paper}

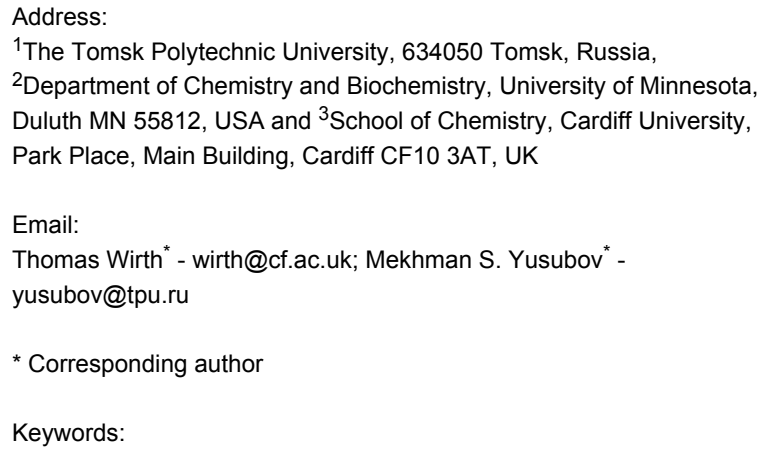

${ }^{1}$ The Tomsk Polytechnic University, 634050 Tomsk, Russia, ${ }^{2}$ Department of Chemistry and Biochemistry, University of Minnesota, Duluth MN 55812, USA and ${ }^{3}$ School of Chemistry, Cardiff University, Park Place, Main Building, Cardiff CF10 3AT, UK

Email:

Thomas Wirth ${ }^{*}$ - wirth@cf.ac.uk; Mekhman S. Yusubov* yusubov@tpu.ru

* Corresponding author

Keywords:

diaryliodonium salts; iodine; iodonium; oxidation; Oxone

\author{
Beilstein J. Org. Chem. 2018, 14, 849-855. \\ doi:10.3762/bjoc. 14.70 \\ Received: 18 February 2018 \\ Accepted: 27 March 2018 \\ Published: 12 April 2018 \\ This article is part of the Thematic Series "Hypervalent iodine chemistry in \\ organic synthesis". \\ Associate Editor: D. Y.-K. Chen \\ (C) 2018 Soldatova et al.; licensee Beilstein-Institut. \\ License and terms: see end of document.
}

\begin{abstract}
A facile synthesis of diaryliodonium salts utilizing Oxone as versatile and cheap oxidant has been developed. This method shows wide applicability and can be used for the preparation of iodonium salts containing electron-donating or electron-withdrawing groups in good yields. In addition, this procedure can be applied to the preparation of symmetric iodonium salts directly from arenes via a one-pot iodination-oxidation sequence.
\end{abstract}

\section{Introduction}

Diaryliodonium salts, which are also known as diaryl- $\lambda^{3}-$ iodanes, are widely considered to be an important and practically useful class of hypervalent iodine compounds [1-4]. Diaryliodonium salts have found broad synthetic application as electrophilic arylating reagents in reactions with various nucleophiles including electron-rich carbon-centered species [5-7]. The unique arylating reactivity of diaryliodonium salts has been demonstrated in many metal-catalyzed and also metal-free transformations [8-15].
The development of novel synthetic approaches to diaryliodonium salts based on the use of inexpensive, commercially available oxidants is an important and challenging goal. A vast majority of existing procedures involve the interaction of electrophilic hypervalent iodine(III) species with suitable arenes through ligand exchange processes [16-20]. The reactive hypervalent iodine(III) species can be used as stable reagents or can be generated in situ [21-25]. In particular, Olofsson and co-workers reported procedures based on the in situ generation 
of reactive $\lambda^{3}$-iodane species directly from arenes, which was a significant achievement in this field [26-29]. However, these now well-established processes involve oxidations using $m \mathrm{CPBA}$ in the presence of strong organic acids [30-35]. Therefore, the development of new, convenient and inexpensive methods utilizing readily available and easy-to-handle oxidants still remains a highly desirable goal.

Previously, we have published the utilization of Oxone ${ }^{\circledR}$ $\left(2 \mathrm{KHSO}_{5} \cdot \mathrm{KHSO}_{4} \cdot \mathrm{K}_{2} \mathrm{SO}_{4}\right)$ as a readily available and effective oxidant for the preparation of various hypervalent iodine compounds [36-42]. Oxone is used as an efficient oxidant for the direct conversion of substituted 2-iodobenzoic acids to arylbenziodoxoles [37,38], 2-iodobiphenyl to dibenziodolium compounds [39], iodoarenes to iodylbenzenes and [bis(trifluoroacetoxy)iodo]arenes [40,41], and for the preparation of diaryliodonium trifluoroacetates and triflates [42]. Yakura also used Oxone ${ }^{\circledR}$ as an oxidant for the generation of iodine(III) species in the oxidation of phenols [43]. In the present work, we report the development of a reliable and convenient procedure for the preparation of diaryliodonium bromides using Oxone in the presence of sulfuric acid.

\section{Results and Discussion}

After having investigated previously described reaction conditions [37,38], initial optimization studies were performed using iodobenzene and toluene as reactants for the synthesis of diaryliodonium salt 3a (Table 1). A simple mixing of the starting materials with finely ground Oxone and sulfuric acid leads to the formation of a very viscous and dark reaction mixture (Table 1, entry 1). Full conversion of the starting materials could not be achieved even after $24 \mathrm{~h}$ stirring. The addition of aqueous $\mathrm{KBr}$ to the reaction mixture resulted in the formation of the desired bromide salt $\mathbf{3 a}$ in $30 \%$ isolated yield. The addition of $\mathrm{KBr}$ is necessary as the high solubility of the diaryliodonium sulfonates does not allow their isolation from the reaction mixture. Dilution of the reaction mixture with dichloromethane did not increase the yield of the target product significantly (Table 1, entry 2). Moreover, we observed the formation of 4-iodobenzenesulfonic acid in both cases, probably due to the high concentration of sulfuric acid in the reaction mixture. Mixing dichloromethane with acetonitrile resulted in an increased yield of $\mathbf{3 a}$ and a decreased amount of 4-iodobenzenesulfonic acid (Table 1, entry 3 ). When the reaction was carried out in pure acetonitrile, the iodonium salt 3a was formed in $75 \%$ yield (Table 1 , entry 4 ). The addition of 2 equivalents of Oxone increased the yield to $92 \%$ (Table 1, entry 5). Surprisingly, a smaller amount of toluene did not affect the yield (Table 1, entry 6). In order to avoid the formation of undesired 4-iodobenzenesulfonic acid, the reaction was carried out using smaller amounts of acid (Table 1, entries 7 and 8). That reaction proceeds smoothly with only 7.5 equivalents of sulfuric acid producing the target compound 3a high yields. However, the use of 3.75 equivalents of sulfuric acid resulted in a significantly lower yield.

With the optimized procedure, the synthetic utility of this method using various aryliodides and arenes was investigated (Table 2). Iodobenzene (1a) smoothly reacts with arenes containing electron-donating substituents to form the corresponding iodonium salts in high yields. 3-Trifluoromethyliodobenzene (1b) exhibited higher reactivity, and iodonium salts have

Table 1: Optimization studies. ${ }^{\text {a }}$

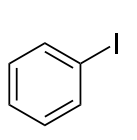

$1 \mathbf{a}$

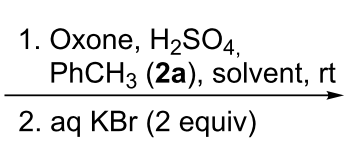

aq $\mathrm{KBr}(2$ equiv $)$

$3 a$

\begin{tabular}{|c|c|c|c|c|c|}
\hline entry & solvent & toluene (equiv) & Oxone (equiv) & $\mathrm{H}_{2} \mathrm{SO}_{4}$ (equiv) & yield $^{b}(\%)$ \\
\hline 1 & - & 2.8 & 1.3 & 15 & $30^{c}$ \\
\hline 2 & $\mathrm{CH}_{2} \mathrm{Cl}_{2}$ & 2.8 & 1.3 & 15 & $40^{c}$ \\
\hline 3 & $\mathrm{CH}_{2} \mathrm{Cl}_{2} / \mathrm{MeCN}$ & 2.8 & 1.3 & 15 & $60^{c}$ \\
\hline 4 & $\mathrm{MeCN}$ & 2.8 & 1.3 & 15 & $75^{c}$ \\
\hline 5 & $\mathrm{MeCN}$ & 2.8 & 2 & 15 & $92^{c}$ \\
\hline 6 & $\mathrm{MeCN}$ & 1.2 & 2 & 15 & $88^{c}$ \\
\hline 7 & $\mathrm{MeCN}$ & 1.2 & 2 & 7.5 & 86 \\
\hline 8 & $\mathrm{MeCN}$ & 1.2 & 2 & 3.75 & 53 \\
\hline
\end{tabular}

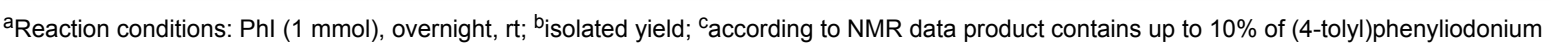
4-iodobenzenesulfonate as an impurity. 
Table 2: Synthesis of diaryliodonium bromides. ${ }^{a}$

$$
\text { 年 }
$$

12

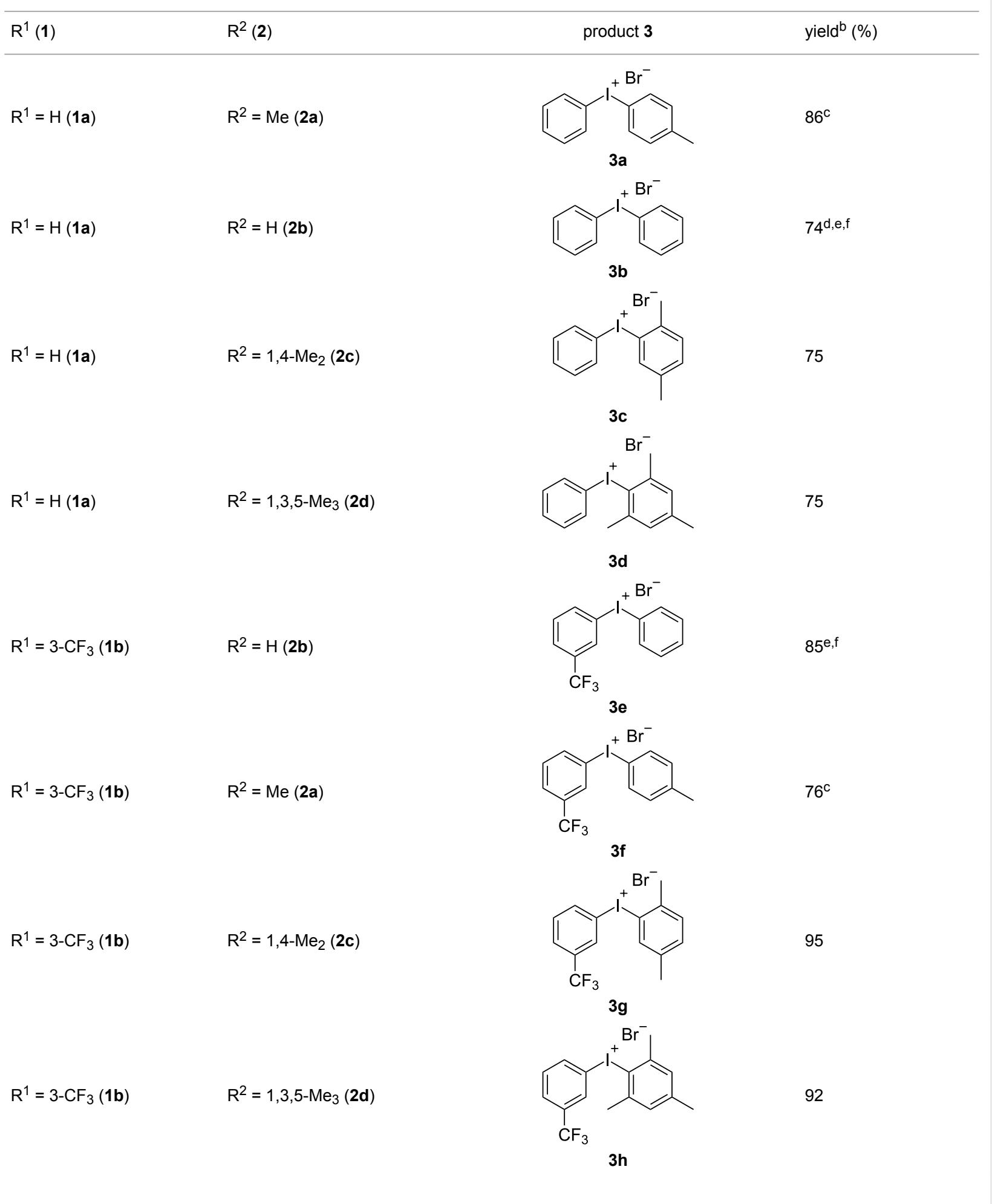


Table 2: Synthesis of diaryliodonium bromides. ${ }^{\text {a }}$ (continued)

$$
\begin{array}{ll}
\mathrm{R}^{1}=3-\mathrm{CF}_{3}(\mathbf{1 b}) & \mathrm{R}^{2}=\mathrm{Cl}(\mathbf{2 e}) \\
\mathrm{R}^{1}=4-\mathrm{Br}(\mathbf{1 c}) & \mathrm{R}^{2}=\mathrm{Me}(\mathbf{2 a}) \\
\mathrm{R}^{1}=4-\mathrm{Br}(\mathbf{1 c}) & \mathrm{R}^{2}=1,4-\mathrm{Me}_{2}(\mathbf{2 c}) \\
\mathrm{R}^{1}=3,5-(\mathrm{CF})_{2}(\mathbf{d}) & \mathrm{R}^{2}=1,3,5-\mathrm{Me} \mathrm{e}_{3}(\mathbf{2 d}) \\
\mathrm{R}^{1}=4-\mathrm{Br}(\mathbf{c}) & \mathrm{R}^{2}=\mathrm{H}(\mathbf{2 b}) \\
& \\
\mathrm{R}^{2}=1,3,5-\mathrm{Me}_{3}(\mathbf{2 d})
\end{array}
$$<smiles>FC(F)(F)c1cccc([I+]c2ccc(Cl)cc2)c1</smiles>

3i<smiles>Cc1ccc([I-]c2ccc(Br)cc2)cc1</smiles>

$3 \mathbf{j}$<smiles>Cc1ccc(C)c([I+]c2ccc(Br)cc2)c1</smiles>

3k<smiles>Cc1cc(C)c([I+]c2ccc(Br)cc2)c(C)c1</smiles>

3I<smiles>Clc1ccc([In]c2ccc(Br)cc2)cc1</smiles>

$3 m$<smiles>FC(F)(F)c1cc([I-]c2ccccc2)cc(C(F)(F)F)c1</smiles>

$3 n$<smiles>Cc1cc(C)c([I+]c2cc(C(F)(F)F)cc(C(F)(F)F)c2)c(C)c1</smiles>

$51^{\mathrm{g}, \mathrm{h}}$

$70^{c}$

30

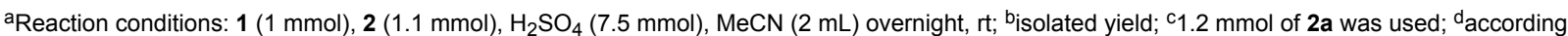
to NMR data product contains an up to $1.5 \%$ of diphenyliodonium 4-iodobenzenesulfonate as impurity; ${ }^{\mathrm{e}} 11.3 \mathrm{mmol}$ of $\mathrm{H}_{2} \mathrm{SO}_{4}$ was used; ${ }^{\mathrm{f}} 1.3 \mathrm{mmol}$ of 2b was used; 915 mmol of $\mathrm{H}_{2} \mathrm{SO}_{4}$ was used; ${ }^{\mathrm{h}} 1.5 \mathrm{mmol}$ of $2 \mathbf{e}$ was used.

been isolated in higher yields. Moreover, iodoarene $\mathbf{1 b}$ reacted with the moderately electron-poor chlorobenzene (2e) forming iodonium salt $3 \mathbf{i}$ in $51 \%$ yield. In contrast, 4-bromoiodobenzene (1c) was less reactive and afforded iodonium salts $\mathbf{3} \mathbf{j}-\mathbf{m}$ in lower yields. Similar reactions of 3,5-bis(trifluoromethyl)iodobenzene (1d) with benzene and mesitylene formed the corresponding iodonium salts $\mathbf{3 n}$ and $\mathbf{3 o}$ in moderate yields.

With electron-deficient arenes 2 such as chlorobenzene (2e) and benzene, an excess of sulfuric acid and arene was used to improve the yields. Subsequently it was shown that the addition of aqueous potassium bromide can be modified and other counter anions can be introduced to prepare different diaryliodonium salts. This has been demonstrated in the preparation of diaryliodonium salts using 1-iodo-3-trifluoromethylbenzene (1b) and mesitylene (2d) as model substrates (Table 3).

The yield of the salts $\mathbf{3 h}$ and $\mathbf{3} \mathbf{p}-\mathbf{s}$ do not depend on the nature of the anion and its source. Small differences in yield can be explained by different solubility of salts in aceto- 
Table 3: Preparation of diaryliodonium salts with different anions. ${ }^{\text {a }}$

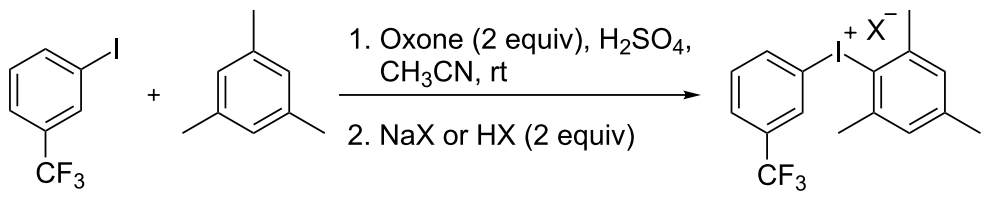

$1 \mathrm{~b}$

2d

3

\begin{tabular}{lll}
\hline $\mathrm{NaX} / \mathrm{HX}$ & product & yield $(\%)$ \\
\hline $\mathrm{NaBr}$ & $3 \mathrm{~h}$ & 92 \\
$\mathrm{TsOH}$ & $3 p$ & 82 \\
$\mathrm{TfOH}$ & $3 \mathbf{q}$ & 89 \\
$\mathrm{NaBF}_{4}$ & $3 \mathbf{r}$ & 81 \\
$\mathrm{NaPF}_{6}$ & $3 \mathrm{~s}$ & 80 \\
\hline
\end{tabular}

aReaction conditions: 1b (1 mmol), 2d (1.1 mmol), Oxone (1 mmol), $\mathrm{H}_{2} \mathrm{SO}_{4}$ (7.5 mmol), MeCN (2 mL), $\mathrm{NaX}$ or $\mathrm{HX}(2 \mathrm{mmol})$ overnight, rt; ${ }^{\text {isolated }}$ yield.

nitrile/water. Diaryliodonium bromides were isolated in higher yields because of the low solubility of these products (Table 3).
Finally, a one-step procedure for the preparation of symmetric iodonium salts directly from arenes via an in situ iodination was developed (Table 4). Arenes $\mathbf{2 b}-\mathbf{e}$ can be transformed to the

Table 4: Preparation of symmetric iodonium salts via a one-step iodination-oxidation procedure. ${ }^{\text {a }}$

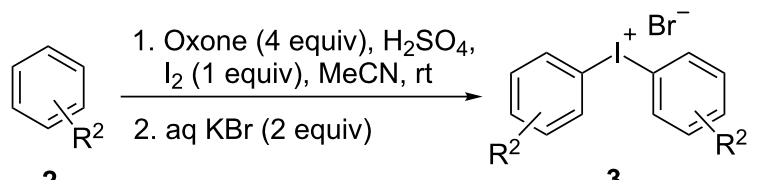

3

\begin{tabular}{lll}
\hline $\mathrm{R}^{2}(2)$ & product 3 & yield \\
& &
\end{tabular}

$\mathrm{R}^{2}=\mathrm{H}(\mathbf{2 b})$<smiles>Br[C+](c1ccccc1)c1ccccc1</smiles>

$\mathrm{R}^{2}=1,4-\mathrm{Me}_{2}(\mathbf{2 c})$<smiles>Cc1ccc(C)c([I+]c2cc(C)ccc2CBr)c1</smiles>

$3 t$

$R^{2}=1,3,5-M e_{3}(2 d)$<smiles>Cc1cc(C)c([I+][I-]c2c(C)cc(C)cc2C)c(C)c1</smiles>

3u

$\mathrm{R}^{2}=\mathrm{Cl}(\mathbf{2 e})$<smiles>Clc1ccc([I+]c2ccc(Cl)cc2)cc1</smiles>

3v

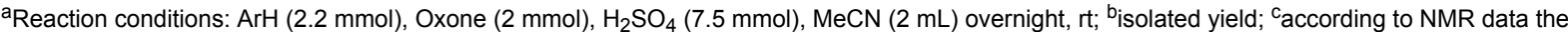
product contains up to $1.5 \%$ of diphenyliodonium 4-iodobenzenesulfonate as impurity; ${ }^{\mathrm{d}} 11.3 \mathrm{mmol}$ of $\mathrm{H}_{2} \mathrm{SO}_{4}$ and 2.6 mmol of $\mathbf{2 b}$ were used; $\mathrm{e}_{15} \mathrm{mmol}$ of $\mathrm{H}_{2} \mathrm{SO}_{4}$ and $3.0 \mathrm{mmol}$ of $2 \mathrm{e}$ were used. 
symmetric iodonium salts $\mathbf{3 b}$ and $\mathbf{3 t}-\mathbf{v}$ by the reaction with iodine, Oxone, and sulfuric acid. The attempted synthesis of the symmetric iodonium salt using toluene as substrate led to a regioisomeric mixture of products due to the low regioselectivity of iodination.

This procedure allowed the synthesis of iodonium salts with arenes containing electron-donating groups. Unfortunately, electron-poor arenes exhibited a lower reactivity and bis-(4chlorophenyl)iodonium bromide have been isolated in only $40 \%$ yield. Nevertheless, the developed procedure is characterized by important advantages, such as simplicity, the use of inexpensive and available reagents, and typically good yields of iodonium salts. It is a versatile addition to the methodology toolbox for the preparation of diaryliodonium salts.

\section{Conclusion}

In conclusion, a new facile protocol for the preparation of diaryliodonium salts using cheap and readily available Oxone as an oxidant in the presence of sulfuric acid has been developed. The procedure allows the synthesis of a wide range of iodonium salts containing electron-donating and electronwithdrawing substituents. Particularly attractive is the possibility of the one-pot synthesis of symmetric bis-aryliodonium salts directly from arenes via an iodination-oxidation sequence.

\section{Supporting Information}

\section{Supporting Information File 1 \\ Experimental details and NMR spectra. \\ [https://www.beilstein-journals.org/bjoc/content/ supplementary/1860-5397-14-70-S1.pdf]}

\section{Acknowledgements}

This work was supported by the Russian Foundation for Basic Research (RFBR-mol_nr 17-33-50111), the Tomsk Polytechnic University Competitiveness Enhancement Program and the Royal Society (IE160304). We thank the EPSRC National Mass Spectrometry Facility, Swansea, for mass spectrometric data.

\section{ORCID ${ }^{\circledR}$ iDs}

Pavel Postnikov - http://orcid.org/0000-0001-9713-1290 Olga Kukurina - http://orcid.org/0000-0001-6017-5628 Viktor V. Zhdankin - http://orcid.org/0000-0002-0315-8861 Akira Yoshimura - http://orcid.org/0000-0002-2577-397X Thomas Wirth - http://orcid.org/0000-0002-8990-0667 Mekhman S. Yusubov - http://orcid.org/0000-0001-9233-1824

\section{References}

1. Yusubov, M. S.; Maskaev, A. V.; Zhdankin, V. V. ARKIVOC 2011, i, 370-409. doi:10.3998/ark.5550190.0012.107

2. Zhdankin, V. V. Hypervalent lodine Chemistry; Wiley: Chichester, 2014.

3. Yoshimura, A.; Zhdankin, V. V. Chem. Rev. 2016, 116, 3328-3435. doi:10.1021/acs.chemrev.5b00547

4. Wirth, T., Ed. Hypervalent lodine Chemistry in Topics in Current Chemistry; Springer: Berlin, 2016; Vol. 373.

5. Merritt, E. A.; Olofsson, B. Angew. Chem., Int. Ed. 2009, 48, 9052-9070. doi:10.1002/anie.200904689

6. Aradi, K.; Tóth, B. L.; Tolnai, G. L.; Novák, Z. Synlett 2016, 27 1456-1485. doi:10.1055/s-0035-1561369

7. Fañanás-Mastral, M. Synthesis 2017, 49, 1905-1930. doi:10.1055/s-0036-1589483

8. Gonda, Z.; Novák, Z. Chem. - Eur. J. 2015, 21, 16801-16806. doi:10.1002/chem.201502995

9. Dey, C.; Lindstedt, E.; Olofsson, B. Org. Lett. 2015, 17, 4554-4557. doi:10.1021/acs.orglett.5b02270

10. Tinnis, F.; Stridfeldt, E.; Lundberg, H.; Adolfsson, H.; Olofsson, B. Org. Lett. 2015, 17, 2688-2691. doi:10.1021/acs.orglett.5b01079

11. Cahard, E.; Male, H. P. J.; Tissot, M.; Gaunt, M. J. J. Am. Chem. Soc. 2015, 137, 7986-7989. doi:10.1021/jacs.5b03937

12. Modha, S. G.; Greaney, M. F. J. Am. Chem. Soc. 2015, 137, 1416-1419. doi:10.1021/ja5124754

13. Beaud, R.; Phipps, R. J.; Gaunt, M. J. J. Am. Chem. Soc. 2016, 138, 13183-13186. doi:10.1021/jacs.6b09334

14. Yin, K.; Zhang, R. Org. Lett. 2017, 19, 1530-1533. doi:10.1021/acs.orglett.7b00310

15. Seidl, T. L.; Stuart, D. R. J. Org. Chem. 2017, 82, 11765-11771. doi:10.1021/acs.joc.7b01599

16. Margida, A. J.; Koser, G. F. J. Org. Chem. 1984, 49, 3643-3646. doi:10.1021/jo00193a039

17. Kitamura, T.; Matsuyuki, J.-i.; Nagata, K.; Furuki, R.; Taniguchi, H. Synthesis 1992, 945-946. doi:10.1055/s-1992-26272

18. Kitamura, T.; Matsuyuki, J.-i.; Taniguchi, H. Synthesis 1994, 147-148. doi:10.1055/s-1994-25423

19. Pike, V. W.; Butt, F.; Shah, A.; Widdowson, D. A. J. Chem. Soc., Perkin Trans. 1 1999, 245-248. doi:10.1039/a809349k

20. Carroll, M. A.; Pike, V. W.; Widdowson, D. A. Tetrahedron Lett. 2000, 41, 5393-5396. doi:10.1016/S0040-4039(00)00861-3

21. Kaźmierczak, P.; Skulski, L. Synthesis 1995, 1027-1032. doi:10.1055/s-1995-4045

22. Kryska, A.; Skulski, L. Molecules 2001, 6, 875-880. doi:10.3390/61100875

23. Hossain, M. D.; Kitamura, T. Tetrahedron 2006, 62, 6955-6960. doi:10.1016/j.tet.2006.04.073

24. Hossain, M. D.; Ikegami, Y.; Kitamura, T. J. Org. Chem. 2006, 71, 9903-9905. doi:10.1021/jo061889q

25. Dohi, T.; Yamaoka, N.; Itani, I.; Kita, Y. Aust. J. Chem. 2011, 64, 529-535. doi:10.1071/CH11057

26. Bielawski, M.; Zhu, M.; Olofsson, B. Adv. Synth. Catal. 2007, 349, 2610-2618. doi:10.1002/adsc.200700373

27. Bielawski, M.; Olofsson, B. Chem. Commun. 2007, 2521-2523. doi:10.1039/b701864a

28. Bielawski, M.; Aili, D.; Olofsson, B. J. Org. Chem. 2008, 73, 4602-4607. doi:10.1021/jo8004974

29. Zhu, M.; Jalalian, N.; Olofsson, B. Synlett 2008, 592-596. doi:10.1055/s-2008-1032050 
30. Jalalian, N.; Olofsson, B. Tetrahedron 2010, 66, 5793-5800. doi:10.1016/j.tet.2010.05.004

31. Seidl, T. L.; Sundalam, S. K.; McCullough, B.; Stuart, D. R. J. Org. Chem. 2016, 81, 1998-2009. doi:10.1021/acs.joc.5b02833

32. Lindstedt, E.; Reitti, M.; Olofsson, B. J. Org. Chem. 2017, 82, 11909-11914. doi:10.1021/acs.joc.7b01652

33. Carreras, V.; Sandtorv, A. H.; Stuart, D. R. J. Org. Chem. 2017, 82, 1279-1284. doi:10.1021/acs.joc.6b02811

34. Gemoets, H. P. L.; Laudadio, G.; Verstraete, K.; Hessel, V.; Noël, T. Angew. Chem., Int. Ed. 2017, 56, 7161-7165. doi:10.1002/anie.201703369

35. Laudadio, G.; Gemoets, H. P. L.; Hessel, V.; Noël, T. J. Org. Chem. 2017, 82, 11735-11741. doi:10.1021/acs.joc.7b01346

36. Frigerio, M.; Santagostino, M.; Sputore, S. J. Org. Chem. 1999, 64, 4537-4538. doi:10.1021/jo9824596

37. Yusubov, M. S.; Yusubova, R. Y.; Nemykin, V. N.; Zhdankin, V. V. J. Org. Chem. 2013, 78, 3767-3773. doi:10.1021/j0400212u

38. Yusubov, M. S.; Soldatova, N. S.; Postnikov, P. S.; Valiev, R. R.; Svitich, D. Y.; Yusubova, R. Y.; Yoshimura, A.; Wirth, T.; Zhdankin, V. V. Eur. J. Org. Chem. 2018, 640-647. doi:10.1002/ejoc.201701595

39. Postnikov, P. S.; Guselnikova, O. A.; Yusubov, M. S.; Yoshimura, A.; Nemykin, V. N.; Zhdankin, V. V. J. Org. Chem. 2015, 80, 5783-5788. doi:10.1021/acs.joc.5b00741

40. Zagulyaeva, A. A.; Yusubov, M. S.; Zhdankin, V. V. J. Org. Chem. 2010, 75, 2119-2122. doi:10.1021/jo902733f

41. Soldatova, N.; Postnikov, P.; Troyan, A. A.; Yoshimura, A.; Yusubov, M. S.; Zhdankin, V. V. Tetrahedron Lett. 2016, 57, 4254-4256. doi:10.1016/j.tetlet.2016.08.038

42. Soldatova, N. S.; Postnikov, P. S.; Kukurina, O. S.; Zhdankin, V. V.; Yoshimura, A.; Wirth, T.; Yusubov, M. S. ChemistryOpen 2017, 6, 18-20. doi:10.1002/open.201600129

43. Yakura, T.; Omoto, M.; Yamauchi, Y.; Tian, Y.; Ozono, A. Tetrahedron 2010, 66, 5833-5840. doi:10.1016/j.tet.2010.04.124

\section{License and Terms}

This is an Open Access article under the terms of the Creative Commons Attribution License (http://creativecommons.org/licenses/by/4.0), which permits unrestricted use, distribution, and reproduction in any medium, provided the original work is properly cited.

The license is subject to the Beilstein Journal of Organic Chemistry terms and conditions:

(https://www.beilstein-journals.org/bjoc)

The definitive version of this article is the electronic one which can be found at: $\underline{\text { doi: } 10.3762 / \text { bjoc. } 14.70}$ 